\title{
MAZAR-I-SHARIF TRIP REPORT \\ SEPTEMBER 28 - OCTOBER 1, 1992 \\ ANDREW WILDER
}

\section{OBJECTIVES}

This mission to Mazar-i-sharif was conducted in my capacity as the ACBAR representative to the UNDP sponsored UN office for the Rehabilitation strategy for Afghanistan (UNORSA). The objectives of the trip were as follows:

1) To familjarize myself with the operations and activities of UNDP and other agencies in northern Afghanistan;

2) To assess the capacity of the UN and NGo system to undertake field reconnaissance activities in northern Afghanistan under the rehabilitation strategy, and to assess the viability of interim rehabilitation strategy activities over the next six months (Note: this subject is addressed in my separate report being prepared regarding an interim rehabilitation strategy.); and

3) To assess the viability of NGOs establjshing operational bases in northern Afghanistan.

\section{TRIP ITINERARY}

September $28-4$ Flew from Peshawar to Mazar, with brief stopover in Faizabad, Badakhshan. Met with Sultan Aziz of UNDP/OPS, and later with a UNV engineer, to discuss the program and projects of UNDP/OPS in northern Afghanistan.

September 29 -- Went on a field mission with sultan Aziz and Jeanette Haizlett of UNDP to Robatak in Baghlan province (near border with Samangan) to visit wash crossing project on MazarKabul highway funded by UNDP/OPS. In the afternoon met with WFP and ILO to discuss their programs in the north.

September 30 -- Went on an all day field mission with FAo to visit cotton seed test plots near Dehdadi, Towkhta and on the state farm at Khasapaz, and to tour the nearby fertilizer factory. Also visited FAO supported veterinary clinic in Shibergan, the provincial capital of Jozjan.

october 1 -- Met with FAO and UHDP. In the afternoon left Mazar for Islamabad by UN plane. 
Most of my time on this trip was spent on field missions with UNDP/OPS and FAO. MY report will therefore concentrate on the activities of these two agencies, as well as on WFP whose main storage facility I was able to visit while in Mazar. other U.N. agencies with a presence in Mazar are UNHCR, UNCHS (HABITAT), UNICEF, WHO, and ILO. ICRC also has an office in Mazar and is running a program for the disabled. As far as I could ascertain, the only NGOs currently operating out of Mazar are MSF and OXFAM.

A. United Nations Development Program, office for Project Bervices (UNDP /OPS)

UNDP/OPS's strategy in northern Afghanistan is to establish District Development Committees (similar if not the same as shuras) to come up with a prioritized list of needs for their district. UNDP/OPS then sends a team of engineers to evaluate the projects to determine which are feasible, and to prepare the necessary technical calculations and drawings. A "Bill of Quantities" is then prepared which is UNDP/OPS's calculations of what it should cost to complete the project. At this stage a "Technical Implementing Group (TIG)" is identified to implement the project. In the wash crossing project we visited, the TIG was a qualified engineer who formerly worked in Peshawar, who was contracted to oversee the implementation of the project. In other cases, the District Development Committee or local shura identifies one or more individuals to serve as the TIG. The project is then monitored on a regular basis by UNDP/OPS.

To date, UNDP/OPS has funded approximately 15 projects from its Mazar office. Most have been related to irrigation although some road repair projects have also been supported. UNDP/OPS intends to expand its activities in the north and has plans to establish three sub-offices in Herat, Pul-i-Khumri, and ( $I$ believe) Bamiyan. Each will be staffed by a project manager and a team of engineers to identify and oversee projects.

\section{B. Food and Agriculture organization (FAO)}

FAO's three main activities in northern Afghanistan are a seed production and training project, a veterinary project, and a sunnpest and locust control'project. ( $I$ was unable to collect much information on the status of the latter.) The seed production and training project recently shifted its office from Kabul to Mazar-iSharif when its focus changed from vegetable seed and fruit saplings to cereal crops. The main activities of this project are variety development, foundation seed production, and certified seed production of wheat, cotton, grain legume, and assorted vegetables; developing seed production facilities on state farms as well as a contract seed growers scheme; equipping and reactivating seed 
testing services at the regional laboratory at Mazar-i-Sharif; distribution and marketing of seed crops; raising quality fruit tree saplings; and training counterpart staff (see Peter otimodch's "Update Project status Report," 9/9/92).

According to Peter otimodch's report, project outputs to date include the following:

a. Screened over 200 advance 1 ines of wheat and are currently screening 40 advance lines of cotton;

b. Planted a total of 10 hectares of wheat and 30 hectares of cotton for foundation seed production;

c. Raised over one million seedlings of assorted vegetables;

d. Planted 210 hectares of wheat on four state farms for certified wheat seed production (although insecurity and land disputes led to the loss of wheat on three of the farms);

e. Raised over 50,000 quality fruit tree saplings;

f. Recruited over 300 private seed growers for wheat and 164 for cotton;

g. Equipped the regional seed testing laboratory in Mazar for purity and germination testing (later looted); and

h. Distributed 1,550 MT of certified wheat seed and 577 MT of certified cotton seed to farmers.

Unfortunately, FAO's seed production project suffered several setbacks due to the looting which followed the collapse of the former government in April. Three of the four state farms were looted and the ownership of the land disputed. The seed production facilities and the certified seed being grown on these three farms were lost. The recently equipped seed testing laboratory in Mazar was also looted. Only the Khasapaz state farm we visited was not looted as tanks were reportedly moved into position to protect it. (On our visit, a tank was still visible protecting one of the entrances to the farm.)

FAO's veterinary program consists primarily of supporting the government veterinary services and preparing a training course for basic veterinary workers. In Dehdadi (Balkh), we visited a site where a veterinary clinic was being built with FAO assistance (the former government clinic had been taken over by a political party). Recognizing the weaknesses of the government system, FAO is increasingly encouraging the privatization of the veterinary system whenever possible. For example, while veterinary medicines and vaccines are provided to a clinic free of charge in the beginning, subsequent supplies are sold to the clinic. This forces the clinic, in turn, to charge for services in order to raise the money necessary to resupply. The FAO Mazar office would eventually like to see the government's role reduced primarily to supplying medicines and vaccines as well as providing training for veterinary workers. 
WFP's head office for its northern Afghanistan program is in Mazari-Sharif. It has sub-offices in Faizabad, Bamiyan, Herat, and Termez. All of its supplies are transported down from the north through Termez. In addition to its own projects, wFP wheat is provided to UNDP/OPS and UNHCR for their projects.

WFP projects include road repair, irrigation, and school repair and construction. Generally, shuras propose projects and WFP approves and provides the wheat for project implementation. WFP's Mazar office has the authority to approve projects requiring up to $80 \mathrm{MT}$ of wheat.

WFP has an impressive facility in Mazar-i-Sharif which holds 16 warehouses with a storage capacity of 1,000 MT each ( 5 more unerected warehouses are also available), fuel storage tanks with a capacity of 80,000 liters, and a weigh station. WFP currently has $8,500 \mathrm{MT}$ of wheat in store and is expecting another 10,000 MT from the EEC and 6,600 MT from Italy. WFP also has 1,500 MT of rice, 500 MT of sugar, and 200 MT of edible oil in stock, and was expecting an additional 1,200 MT of edible oils in the future.

WFP in Mazar expressed its concern about the winter food situation in the north. It predicts serious shortages as the fall harvest is expected to be poor. Furthermore, the wheat silos in Mazar and Pul-i-Khumri are empty and the one in Herat nearly empty.

\section{VIABILITY OF NGOS ESTABLISHING OPERATIONAL BASES IN NORTHERN AFGHANISTAN}

During this three day trip it was clearly not possible to look at all the factors that would relate to NGOs opening up offices in northern Afghanistan. For example, I met with no government authorities to discuss their views or policies regarding NGO activities in the north. While I cannot address all the practicalities of opening an office, I can say that there is a real need for greater NGO involvement in the north, that the UN agencies I met with in Mazar were interested in cooperating with and supporting NGO activities, and that at present the security situation is sufficiently good to allow NGOs to implement programs in several areas in the north.

For someone who has spent the last three years working in Peshawar, the virtual nonexistence of NGOs in Mazar was striking. With few exceptions, NGOs involved in cross-border programs in Afghanistan have been based in Pakistan and have implemented the vast majority of their programs in the eastern and southern provinces of Afghanistan. Obvious security and logistical considerations led to this situation, as well as, the fact that most major donors of NGo projects had their offices in Pakistan. While this approach was 
undoubtedly necessary in the past, and to a considerable extent can still be justified today, there has been a price to pay in terms of the rehabilitation and development of the country. For example, prior to the war the northern provinces produced $75 \%$ of Afghanistan's wheat. To date, however, they have received a fraction of the improved wheat seed and fertilizer inputs that have been provided to the eastern and southern provinces. If we are to achieve the important objective of restoring wheat production to pre-war levels, this imbalance will have to be redressed.

In discussions with UN agencies based in Mazar on this topic, all were interested in seeing an increase in the level of NGO activities in the north, and expressed their willingness to cooperate with and support such activities. The strategy guiding UNDP/OPS's operations in northern Afghanistan was designed to respond to a situation where there were no NGOs through which it could implement its programs. UNDP/OPS staff must therefore do much of the work which in other areas is done by NGOs. When questioned, UNDP/OPS staff were very interested in having more NGOs begin activities in the north, and were open to the idea of using NGOs as Technical Implementing Groups (TIGs). Similarly, WFP, FAO and ILO also expressed an interest in having NGOs as implementing partners. Several UN staff noted the weakness of the government institutions and their inability to serve as effective implementing partners, and expressed an interest in working more closely with NGos to provide services.

While the need to increase NGo activities in the north is clearly there, and for many NGOs probably the willingness to do so, the obvious question arises of who will pay. While UNDP/OPS might provide some funding for a small irrigation project, and FAO might provide some improved seeds and fertilizer, and WFP might provide several tons of wheat, who will pay for the overhead and administrative costs of opening and running an office in Mazar? UN agencies have generally been unwilling or unable to adequately fund such costs and NGOs have had to turn to other donors to cover the costs of administering UN projects. Unless the UN changes its policies in this regard, or until NGOs find other donors willing to cover the costs of opening and funding the running costs of an office, NGOs are unlikely to be able to make the move north.

While funding will undoubtedly be a problem for many NGOs, and although security and logistical concerns are certainly still present, it is time for NGOs, and NGo donors, to seriously consider the possibilitylof expanding their activities to the north. The continued provision of assistance in unbalanced proportions regionally threatens to result in uneven rehabilitation and development at a national level. It is therefore imperative that NGOs adopt a more national perspective and begin to redress the regional imbalances which have by necessity marked the provision of NGO assistance to Afghanistan in the past. 


\section{ANECDOTES AND OBSERVATIONS}

The following anecdotal information and observations reflect the fact that most of my time was spent on field missions with UNDP/OPS and FAO; and as a result important sectors such as health and education are not even touched upon.

\section{A. General situation:}

1) On the surface, at least, there is a real feeling of normality in the city of Mazar. The streets were full of traffic and the bazaar was bustling and full of activity. Mountains of melons were being sold on the roadsides, and fruit and vegetable vendors were everywhere. Sidewalk stalls sold everything from ice cream cones and french fries to used books and soaps and shampoos. Second-hand clothes dealers seemed to be doing a booming business, possibly as winter weather was on its way. Rows of veiled women sat behind piles of nan which they would sell to passers by. Carpets were on display on the fences and sidewalks surrounding the shrine of Hazrat Ali. The general impression I got was of a thriving Asian bazaar.

2) In the city of Mazar, no civilians carried weapons (at least visibly). The only weapons I saw were carried by uniformed personnel. The heavy weaponry defending the offices of the major political parties provided a cautionary note that the political situation is not normal and that the air of normality in the bazars could be deceptive.

\section{B. Agriculture:}

1) Near Akchah in Jozjan we stopped to look at the centuries old sight of a camel plodding around in circles drawing water from a Cartesian well. Nearby was the big mud-walled house of the owner of the well, which could also have been a sight seen by travellers several centuries ago. The only incongruity which could date the scene (apart from the UN Landcruisers) was an anti-aircraft gun and a machine gun mounted on two corners of the mud-walls.

2) Donors and NGOs need to direct more resources towards developing the agricultural sector in the northern provinces which, at least for wheat and cotțon, have traditionally been the most productive. The top priority should be rehabilitating irrigation systems followed by providing improved seeds and fertilizer.

3) According to those who have gone up to Uzbekistan, as soon as you cross the Amu Darya river you enter lush green fields which stand in stark contrast to the desolate plains of northern Afghanistan (the Soviets apparently would not permit Afghanistan to use water from the Amu Darya for irrigation). 
Evidently the Soviets did have plans to develop a big irrigation scheme in the north using the waters of the Kokchah river (the plans and blue prints are reportedly in Kabul). When the situation in Afghanistan stabilizes, donors such as the World Bank or Asian Development Bank (ADB) should study the viability of such a scheme as agricultural production could be greatly increased if some of the northern plains could be irrigated.

4) The Mazar fertilizer factory is urgently in need of financial assistance to enable it to continue producing urea. It is still operating but only at one third to one half its capacity. The Director informed us that the factory only had sufficient raw materials to continue producing at its current level for another month. Donors should consider short-term emergency funding to buy raw materials and essential spare parts to keep the factory operational. The fertilizer is essential to increase agricultural productivity. Furthermore, it is one of the few operational industries Afghanistan has left, it employs 3,000 people including 300 women, and it generates the power for Mazar city. A major donor such as the World Bank, ADB, or USAID should also conduct a study of the longer term issues that will confront the factory such as finding spare parts for the antiquated soviet machinery. Eventually, a major project to modernize and upgrade the facility will inevitably be required. However, donors should not let the longer term issues let them lose sight of the fact that the factory is still producing and in the short term simply needs hard currency to buy some the raw materials to continue production. There was one report that the Iranian government might provide financial assistance to the factory.

5) Virtually all agricultural machinery in the north is of soviet origin. Reportedly it has already become difficult to find spare parts and the process of cannibalization has already begun. Eventually all the machinery will have to be replaced. It may be a natural market for Pakistani manufactured farm machinery.

6) In Mazar we saw a large lot filled with tractors, threshers and other farm machinery sitting idle. Following the change in government, the Ministry of Agriculture's farm machinery rental system collapsed. There was also probably a reluctance to use any of the machinery for fear that it might be looted. According to FAO, the lack of farm machinery combined with labor shortages resulted in a considerable amount of wheat not being harvested and simply rotting in the fields.

7) One FAO official noted that there was a shortage of basic farm tools and that those you could $f$ ind were of very poor quality. He observed that you could buy satellite dishes but not ploughs in the bazaars of Mazar. Although the market would 
have to be examined more closely, it might be possible for an NGO to set up a vocational training or income generation program to produce farm tools.

8) Dr. Tunwar, FAO's Chief Technical Adviser for the Seed Production and Training Project, noted that there was a lot of room to increase agricultural productivity simply through extension training to improve the agricultural practices of the farmers: He noted, for example, that most farmers were using $50 \%$ more seed (both for cotton and wheat) than standard seeding rates which resulted in a great waste of seed.

9) In Shibergan, Dr. Tunwar pointed out a bag of government wheat seed which was of very poor quality (approximately 15 different varieties of wheat were all mixed together).

10) Ministry of Agriculture institutions (i.e. State farms, veterinary programs, extension programs, etc...) seem to have collapsed. The impression $I$ received talking to U.N. officials who had been working with these institutions for the last few years was that the collapse of the former government in April was simply the coup de grace -- the process had begun long before. Several noted how poorly motivated and ineffective the Ministry of Agriculture employees generally were, possibly due to very low salaries. While preparing a rehabilitation strategy and devising policies for the future, donors should examine the effectiveness of the former institutions before they decide to simply re-establish them. There might now be a unique opportunity to rebuild an agricultural system as free of government controls as possible.

11) Agriculture is the basis of Afghanistan's economy and major donors should be encouraged to begin their support now to continue the rehabilitation of this sector. There does not have to be a political settlement in Kabul before work in the agricultural sector can begin. Time should not be lost as agricultural productivity needs to be increased, both to support the existing and returning population of the country as well as to create the surpluses necessary to stimulate economic development.

\section{Roads :}

1) The road I travelled on from Shibergan (Jozjan) to near Pul-iKhumri (Baghlan) was in excellent condition. We travelled most of the time at over $100 \mathrm{~km} / \mathrm{hour}$. Only about a $20 \mathrm{~km}$. stretch of the highway from Mazar east past the airport was rutted and full of potholes. Due to the good condition of the main highway, road repair would not have to be as high a priority in this area as it would in others (i.e. Kabul Kandahar - Herat). 
2) Labor shortages in the north will be a constraint when it comes to labor-intensive rehabilitation activities such as road construction and repair.

3) In Shibergan, roadside shops were being bulldozed and fresh tarmac being laid down in an apparent effort to widen the main roads of the town (possibly as part of a beautification plan for the boss's home town).

4) Although traffic was certainly not heavy, there were a fair number of trucks carrying containers ( $I$ 'm not sure of what) down from Termez towards Kabul. Most other traffic consisted of Mercedes coaches carrying passengers, tractors and trailers, and military trucks, jeeps and tanks. close to Shibergan we passed two of the blue and cream colored Kabul city Tata buses which the driver of our vehicle said had been looted from Kabul. On another occasion, we saw an Ariana Airlines van carrying passengers which had also reportedly been looted from Kabul.

5) From Mazar to Pul-i-Khumri there were guard posts every 3-5 kms. and road blocks every 10-15 kms. At the latter, civilian vehicles were reportedly being taxed (probably to pay salaries), but apparently not at extortionate rates. For example, at one such road block we were travelling behind a tractor trailer carrying wood, which simply had to throw off 5-6 pieces of wood before it was waved on. Bus drivers in Mazar, however, were complaining that all this "taxing" was making the trip to and from Kabul unprofitable.

\section{Refugees:}

1) The impression I got driving through these four provinces was that while the cities and towns were still inhabited, many of the villages were still abandoned and most of the houses destroyed.

2) On a few occasions driving through rural areas we did see mud bricks being made and houses constructed. We assumed that these were refugee returnees, but the one time we stopped and asked the workers informed us that they were not refugees and that they were simply building a new house.

3) UNHCR staff are reportedly finding that many of the under 20 population of refugee returnees are unhappy to have returned. The adjustment to village life must be a difficult one for the refugees who have grown accustomed to greater opportunities in the areas of employment, education, health, and entertainment. Furthermore, for those who served as mujahideen, many are undoubtedly finding that wielding a shovel is not as exciting as wielding a kalishnikov. 
4) There were reports of many displaced people from the Kabul fighting living in Mazar. Several people gave estimates/guesses of 100,000 but I doubt any reliable figures exist. Some displaced people were reportedly being housed in schools. Several people commented on how much more crowded the bazaars were than usual, and that there were many more unveiled women (presumably from Kabul) than usual. No one spoke of the problem of displaced people in Mazar as an emergency situation. In general, I would guess that anyone who made the effort to' go all the way to Mazar probably did so as they had relatives or friends to stay with. 